\title{
Gender Mainstreaming: A Participatory Impact Assessment of Livelihood Interventions among the Tribal Farm Families in Odisha, India
}

\author{
J. Charles Jeeva*, Gayatri Moharana, Kushagra Joshi, B.C. Behera and Subrat Kr. Das
}

ICAR-Central Institute for Women in Agriculture, Bhubaneswar-751 003, Odisha, India

*Corresponding author

\begin{tabular}{|l|}
\hline Ke y w o r d s \\
Gender \\
mainstreaming, \\
Impact assessment, \\
Livelihood, Tribal, \\
Farmwomen, \\
Nutrition
\end{tabular}

Keywords

Gender

Impact assessment

Livelihood, Tribal,

Farmwomen,

Nutrition

rticle Info

20 June 2019

10 July 2019

\section{A B S T R A C T}

This study was undertaken to document the gendered access to assets, to assess and improve the nutritional status of tribal women and children, to facilitate capacity building and skill upgradation through need based and sustainable interventions for improving livelihood and to document the impact. The sample of the study include 160 tribal families from two clusters of tribal villages in Shamakhunta block in Mayurbhanj district and R. Udayagiri block of Gajapati district in Odisha. The analysis of gendered access to assets revealed that $94 \%$ of the assets were with male; and almost $60 \%$ of the activities in crop production and $85 \%$ of activities in livestock management were performed by women. The project built the capacity of tribal families and grassroots institutions, enhance the access of poor tribal people to knowledge and innovations to increase the productivity of the resources in environmentally sustainable and socially equitable ways. Women from tribal communities were empowered with requisite knowledge and skills and trained in leadership. It was ensured that they are engaged in viable income generating activities through improved skills and livelihood support, and increased knowledge on household food and nutritional security. Outcome of this study would help in formulating gender based policy and services, enhancement of farm production for greater nutritional security of farm families, income and employment generation, drudgery reduction, improved health and nutritional status of women and children, empowerment of the tribal women, improvement in living standards, integrated development of the tribal families, and database having high practical utility for understanding the performance of gender based technological and social interventions in tribal ecosystem.

\section{Introduction}

To accelerate development, it is necessary that the rural women participate and contribute effectively to development efforts. Womenheaded households are on the increase as a result of economic recession, changing labour needs, increasing urbanisation, and the breakup of extended family structures. Women- headed households are usually more vulnerable in times of crisis, as they have fewer resources to draw upon (Mayoux, 1999). Livelihood strategies do not merely refer to narrowly defined economic practices. Rather, livelihood strategies involve transformative struggles through which women work to empower themselves by reshaping their identities, lives and 
relationships within households and communities (Ann et al., 2004). The economic development of women and men depends on availability of income generating activities, their formation as groups, rewarding of their efforts and skills and their ability to participate equally.

Nearly $22 \%$ of the population of Odisha are tribal, whose position is probably not the best in the country. The tribal population of Odisha is $8.15 \mathrm{~m}(22.13 \%)$, and $44.21 \%$ of the total land area is classified as scheduled (Sahoo, 2011). The tribal villages in the State are backward in scenario of economic development, livelihood enhancement and educational development also. People by and large depend on forest and agricultural products, daily labourers and allied activities. Most of them are under below poverty line. Animal husbandry and petty business are also one of the sources of livelihood for these people. There are various factors influencing directly and indirectly the development process. Illiteracy, ignorance, insufficient awareness and lack of organized effort appear to be the root cause of the major problems of socio-economic, educational, health and backwardness of these people. A small land base, low agricultural productivity and low incomes have led to rising indebtedness, trapping tribals into a vicious circle of exploitation. By and large, the benefits of development programmes are yet to reach the tribal population in general. Many time, questions are raised but whether the pattern of development so far adopted are in accordance with the tribal people, their cultural need and livelihood requirements? Whether adequate attention for the welfare of the tribal communities has been given at large?

In this background, this study was conducted in Mayurbhanj and Gajapati districts in Odisha, wherein the Tribal Sub Plan Schemes of ICAR-Central Institute for Women in
Agriculture, Bhubaneswar was implemented. During the initial Knowledge, Attitude and Practice (KAP) survey in the study area, the existing livelihood activities and extent of involvement of women were identified as; crop husbandry with paddy, groundnut, green gram, red gram, cowpea, maize, sweet potato, mustard etc., animal husbandry with goatry, poultry, cattle and sheep rearing, and vegetable cultivation (brinjal, tomato, chilly, gourds, cauliflower, leafy vegetables etc.). Women also make artifacts using safai grass and plates using sal leaves. In all the activities, women's involvement is more than $90 \%$. The constraints identified were; damages to the crops and animals due to frequent floods, silt accumulation and blocking of irrigation canals due to floods, soil erosion and washing away of farm lands due to floods, damages to infrastructural facilities like houses and roads, indebtedness to private money lenders, inadequate infrastructural facilities and inadequate medical facilities. The perceived needs were; critical inputs like quality seeds / seedlings of vegetables, water proof containers for grain storage, animal health service to protect livestock, gender friendly farm tools which help them in reducing drudgery as well as saving time, nutritional issues, human health care, and alternate livelihood/ entrepreneurship development. With these needs assessed, the Institute adopted two clusters of cyclone (Phailin) affected tribal villages in Shamakhunta block in Mayurbhanj district and R. Udayagiri block of Gajapati district for subsequent interventions which consisted of enhancing livelihood option by short-term and long-term research and extension interventions.

In this context, this study was undertaken to document the gendered access to assets, resource base and researchable issues in the tribal eco-system, to assess and improve the nutritional status of tribal women and children, to facilitate capacity building and 
skill upgradation through need based and sustainable interventions for improving livelihood and to conduct participatory monitoring and evaluation to document the impact and research and extension gaps.

\section{Materials and Methods}

The sample of the study include 160 tribal families from two clusters of tribal villages in Shamakhunta block in Mayurbhanj district and R. Udayagiri block of Gajapati district in Odisha. Mixed methods research approach was followed for collecting qualitative and quantitative data using focussed group discussions, key-informant interviews, and in depth household interviews. Mapping the resource-base of the eco-system was done using participatory tools (PRA tools) such as transect walk, resource map and mobility map and interaction with local leaders and key informants. Documentation of demographic profile, identification of gaps and prioritization of needs, and researchable issues were carried out through stakeholder meetings, group interactions, field work and interview schedule based formal and informal surveys. Capacity building and skill upgradation on various short-term and longterm interventions were implemented through need based and sustainable interventions for improving livelihood and increasing occupational productivity by way of conducting frontline demonstrations/ training programmes and awareness creation/ knowledge creation and extension educational programmes followed by distribution of critical inputs to support adoption. Nutritional assessment studies were carried out by collection of anthropometric data, data on food consumption pattern, observing clinical sign \& symptoms of nutritional disorders, Knowledge, Attitudes and Practices (KAP) scores of mothers on nutrition and child care practices. Concurrent and terminal monitoring, evaluation and impact assessment was done using participatory tools and interview schedule based surveys (baseline and endline surveys). Review of secondary information was done through comprehensive literature search from relevant secondary sources and analysis for in depth information support.

The impact assessment of interventions was done in a participatory mode. There are many definitions of participatory monitoring, evaluation and impact assessment, but perhaps the simplest is keeping track of changes with the community stakeholders. The participatory process involves narrowing the gap between research organizations' and farmers' realities by ensuring direct farmer involvement at different stages of research process (Hellin et al., 2006). If the research scientists and the innovative farmers get together in research and development of agricultural technologies, they could be more efficient and useful for the welfare of the country and farming communities (Reddy, 2006).

\section{Results and Discussion}

\section{Socioeconomic Profile and Gendered Access to Assets}

The analysis of demographic profile revealed that the respondents had an average farming experience of $20 \mathrm{yrs}$. The mean land holding size was 1.2 acres. Average number of productive working days in a year was found to be 265 days. Average annual income was reported as Rs. 41,125/- with the percentage contribution from different sectors such as, crops $(38 \%)$; livestock (24\%); wage earning $(21 \%)$ and, others including forest based $(17 \%)$. Average size of households was 6 . Limited social mobility to an extent of 12-20 $\mathrm{km}$ was observed among men, and among the women, it was $6-12 \mathrm{~km}$. The literacy rate was $36 \%$ among male and $17 \%$ among female. The predominant information sources utilized were friends/ neighbours/ peer groups $(75 \%)$ for 
getting agricultural knowledge. Mass media utilization was almost nil among farmwomen. The analysis of gendered access to assets (Land, House, Livestock, Farm Implements, Capital) revealed that $94 \%$ of the assets were with male; and almost $60 \%$ of the activities in crop production and $85 \%$ of activities in livestock management were performed by women. Women work for longer hours and participate in most of the field works related to crop production and have a significantly higher involvement in livestock production, forest resource production and fishery. The farm women perform almost each and every agricultural activities right from land preparation, sowing, harvesting and storage of agricultural produce.

Lipishree (2015) based on her study in a coastal district of Odisha reported that rural women in Odisha play a significant role in agriculture and allied operations. They are actively participating in all range of agricultural activities including pre-harvesting, and post-harvesting. The rural women, besides looking after the family and performing all sorts of household activities, very actively remain busy from dawn to dusk in such agricultural operations which supplements their family income. But despite such a huge contribution, her role has yet not been recognized. Rural women area largely took part in homestead gardening, harvesting crops, post-harvest operation, selling labour, sewing katha, 'buying daily necessities' and rice husking by dhekhi. Women were involved in various activities in order to meet basic family needs, increase family income and meet additional family requirements. The values of correlation coefficient (r) indicated that age of the respondents, amount of indebtedness of the family and family size were positively, and level of education and size of landholding are negatively associated with the participation of rural women in various agricultural and nonagricultural activities, whereas, average annual income and wage rate have no significant relationship with their participation in various activities (Farid et al., 2009).

\section{Studies on food consumption pattern}

An assessment was made to observe the food consumption pattern. The information on change in food intake during different seasons and lean days was also recorded. The survey was conducted in participatory approach, using 24 hours recall method. The diet of the tribe 'Mundas' primarily consists of cereals, vegetables, and products from animal sources. Though they cultivate pulses, their consumption is very less as compared to cereals and vegetables. Seasonal vegetables and fruits are also consumed if grown/ available in the backyard/ field/ forest. Consumption of milk and milk products were observed in the families where they were having milch animals. However the consumption of ghee/ oil was observed to be poor. Rice, potato and green leafy vegetables are the staple food and consumed four-times a day. In some of the families, intake of flaked rice/ puffed rice as breakfast was observed. Consumption of rice and non-vegetarian (meat) dishes are considered to be socially prestigious, which are mostly preferred during festivals and ceremonies along with the indigenous liquor, Mahua.

\section{Nutritional assessment studies}

For assessing nutritional status of children of tribal farm families, anthropometric measurements and clinical examination of 43 children belonging to $1-10$ age group was carried out. Three nutritional indices such as "weight for age z score" (WAZ), "height for age z score" (HAZ) and "BMI for age score" (BAZ) were calculated using World Health Organization (WHO, 2007) standards. Out of the total sample, more than half $(62.79 \%)$ the children had normal weight as per their age. 
Table.1 Participatory Impact Assessment of Interventions

\begin{tabular}{|c|c|c|}
\hline Issues Identified & Interventions & Impact \\
\hline $\begin{array}{l}\text { Lack of scientific vegetable } \\
\text { cultivation }\end{array}$ & \multirow[b]{2}{*}{$\begin{array}{l}\text { Nineteen field level programmes covering } 340 \\
\text { beneficiaries, consisting of skill upgradation } \\
\text { on improved methods of vegetable cultivation, } \\
\text { stakeholder meetings for assessing the seed } \\
\text { needs, input support programme by } \\
\text { distributing mini kits of seeds. } \\
\text { Additional income generation through intercrops } \\
\text { (40) } \\
\text { Awareness creation on vegetable production in low } \\
\text { cost poly houses (20) Materials including } 200 \\
\text { micron polythene sheets and insect proof nets } \\
\text { were distributed to install a } 70 \text { sq. m poly } \\
\text { house. } \\
\text { upgradation on improved methods of } \\
\text { vegetable cultivation ( } 40) \\
\text { Homestead nutrition gardens ( } 40) \\
\text { Input support programme by distributing mini kits } \\
\text { of seeds for vegetable cultivation ( } 60) \\
\text { Advisory on the drudgery reducing implements (20) } \\
\text { Nutrition education (60) } \\
\text { Awareness on scientific and hygienic storage of } \\
\text { food grains ( } 60 \text { ) } \\
\text { Method demonstration of sunflower as intercrop in } \\
\text { potato. Input support of hybrid sunflower } \\
\text { seeds. }\end{array}$} & \multirow{2}{*}{$\begin{array}{l}\text { About } 10 \% \text { increase in mean annual gross family } \\
\text { income }(40,950 \text { to } 45,825) \\
\text { About } 7 \% \text { increase in woman days- Number of } \\
\text { woman-days per year increased from } 265 \text { to } \\
285 \text { per year. } \\
\text { An additional income of Rs. } 8000 \text { /acre realized from } \\
\text { sunflower as intercrop }\end{array}$} \\
\hline $\begin{array}{l}\text { Need for quality planting } \\
\text { materials }\end{array}$ & & \\
\hline Drudgery & $\begin{array}{l}\text { Demonstration of maize dehusker cum sheller } \\
\text { Awareness creation on drudgery reducing farm } \\
\text { tools and distribution of hampers of women- } \\
\text { friendly farm tools (khurpi, vegetable cutter, } \\
\text { improved sickle, hand cultivator, ring cutter, } \\
\text { tubular maize sheller) }\end{array}$ & $\begin{array}{l}\text { Traditional/ Manual maize dehusking and shelling } \\
\text { Output: } 17 \mathrm{~kg} / \mathrm{hr} \\
\text { Pain in upper and lower extremities } \\
\text { Injuries in finger tips \& wounds in palms } \\
\text { DRWA Maize Dehusker-cum-Sheller } \\
\text { Output : } 60 \mathrm{~kg} / \mathrm{hr} \\
\text { Reduces injuries in palms and fingers } \\
\text { Lesser fatigue } \\
\text { Increased awareness (87\%) of farmwomen on } \\
\text { improved farm tools \& equipments }\end{array}$ \\
\hline $\begin{array}{l}\text { Post-harvest loss of food } \\
\text { grains during flash floods }\end{array}$ & $\begin{array}{l}\text { Skill upgradation on scientific \& hygienic storage of } \\
\text { grains } \\
\text { Distribution of metallic grain storage bins }\end{array}$ & $\begin{array}{l}\text { Perception index of } 90 \% \text { as; } \\
\text { Loss due to insect/rat infestation minimized } \\
\text { Hygienic storage } \\
\text { Relatively safe during flooding } \\
\text { Effective pest management }\end{array}$ \\
\hline $\begin{array}{l}\text { Inadequate animal health } \\
\text { care }\end{array}$ & $\begin{array}{l}\text { Organization of animal health camps } \\
\text { Number of animals treated } \\
\text { Gajapati }-750 \\
\text { Mayurbhanj-550 } \\
\text { Distribution of feed concentrates } \\
\text { Vaccination and mass treatment }\end{array}$ & $\begin{array}{l}\text { Perception index of } 73 \% \text { as; } \\
\text { Improved overall health status of animals } \\
\text { Free from parasitic infestations } \\
\text { Improved work efficiency of bullocks }\end{array}$ \\
\hline $\begin{array}{l}\text { Inadequate human health } \\
\text { care/ Nutritional issues }\end{array}$ & $\begin{array}{l}\text { Assessment of nutritional status } \\
\text { Anthropometric measurements } \\
\text { Clinical examination } \\
\text { Medical camps ( } 2 \text { Nos.) } \\
\text { Nutrition education programmes (4 Nos.) }\end{array}$ & $\begin{array}{l}\text { Among the total children studied, } 32.56 \% \text { were } \\
\text { underweight, } 39.53 \% \text { were stunted and } \\
18.60 \% \text { showed thinness } \\
\text { Improved awareness ( } 76 \% \text { ) on the significance of } \\
\text { consumption of nutritious vegetables, tubers } \\
\text { and fruits available in their locale }\end{array}$ \\
\hline
\end{tabular}


The percentage of underweight in the studied group was found to be $32.56 \%$. Gender difference was observed as the incidence of underweight was more among boys (35\%) than girls $(30.43 \%)$. As indicated by HAZ scores, $55.81 \%$ children attained normal height, $20.48 \%$ were stunted and a few $(2.41 \%)$ were tall. Stunting was prevalent more among boys (50\%) than girls $(30.43 \%)$.

The data pertaining to the BMI scores of the children shows that out of the total sample studied, $65.12 \%$ had normal nutritional status. A few children were moderately undernourished $(9.30 \%)$ and severely undernourished (9.30\%). About $17 \%$ were found to be overweight.

Gender differences were observed as $13.04 \%$ girls were found to be severely malnourished and $8.70 \%$ girls moderately undernourished in comparison to boys among whom prevalence of severe malnutrition and moderate under nutrition was $5 \%$ and $10 \%$, respectively.

\section{Clinical signs of nutritional deficiencies}

Clinical signs for various nutritional deficiencies were also observed. Children were examined for clinical signs of some deficiency diseases. Children had symptoms for vitamin A deficiency. Pale conjunctiva was observed in $39.5 \%$, and $4.65 \%$ children reported for night blindness. Pale conjunctiva may also be indicative of iron deficiency among the studied population. Pallor $(16.28 \%)$ and pigmentation $(11.63 \%)$ of skin was observed suggestive of skin infections. Deficiency of Vitamin B complex was also observed in selected children in the form of symptoms like pale (16.28\%), magenta $(2.33 \%)$ and red raw (2.33\%) tongue. Overall oral hygiene was poor among the children. Decayed, missing and filled teeth (DMF) were observed in $18.6 \%$ and dental mottling was observed in $11.63 \%$.

\section{Capacity building and skill upgradation} through need based and sustainable interventions for improving livelihood

The interventions carried out were; drudgery reduction by distributing hampers of womenfriendly farm tools and introduction of maize dehusker cum sheller; promotion of nutrition gardens; scientific and hygienic storage of grains for prevention of post-harvest losses; distribution of metallic grain storage bins; organization of animal health camps; skill upgradation; organization of farmers' fairs; facilitating capacity building through need based interventions for improving livelihood such as additional income generation through intercrops, awareness creation on vegetable production in low cost poly houses, skill upgradation on improved methods of vegetable cultivation, periodical Interfaces and monsoon advisory services by multidisciplinary team, input support programme by distributing mini kits of seeds for homestead gardens and drudgery reducing tools.

\section{Participatory impact assessment}

As the project came to an end in 2017, participatory impact assessment of interventions was carried out, and the findings have been summarized in Table 1 .

Awareness was created on scientific and hygienic storage of food grains to prevent post-harvest losses, with the use of metallic grain storage bins provided, the tribal farm families perceived effective storage without pest and rat attack. Upgraded the skills and knowledge of farm women on improved farm tools and equipment. Created awareness on the significance of consumption of nutritious vegetables, tubers and fruits available in their locale. By organizing animal health camps, the health status of animals improved significantly, which are their secondary 
source of livelihood. The tribal farm families reported that, after getting treated in the camp, the animals were free from parasitic infestations such as round and flat worms, and realized the improved work efficiency of bullocks.

The livelihoods and food security of poor tribal households are sustainably improved through promoting a more efficient, equitable, self-managed and sustainable exploitation of the natural resources at their disposal for increased productivity. To achieve this, the project built the capacity of tribal families and grassroots institutions, enhance the access of poor tribal people to knowledge and innovations to increase the productivity of these resources in environmentally sustainable and socially equitable ways. The role of women in tribal areas got highlighted. Women from tribal communities were empowered with requisite knowledge and skills and trained in leadership. It was ensured that they are engaged in viable income generating activities through improved skills and livelihood support, acquired knowledge on scientific storage of food grains and minimizing post-harvest losses, and increased knowledge on household food and nutritional security.

Outcome of this study would help in formulating gender based policy and services, enhancement of farm production for greater nutritional security of farm families, income and employment generation, drudgery reduction, improved health and nutritional status of women and children, empowerment of the tribal women, improvement in living standards, integrated development of the tribal families, and database having high practical utility for understanding the performance of gender based technological and social interventions in tribal ecosystem. The study also recommends formation of women knowledge groups, taking up agripreneurship by linking backyard poultry with mid-day meal programme., mitigating occupational health risk and drudgery reduction of farmwomen at household and farm level, facilitating custom hiring centres for farm implements to reduce drudgery, machinery for value addition to farm produces, awareness creation on land rights, and increasing access to extension services. Extension machinery has to go ahead with gender-friendly check list, and addressing the challenges faced by farmwomen through integrated approach.

\section{References}

Ann, M. O., Jennifer, L. M. and Holly, M. H. 2004. Gendered livelihoods in diverse global contexts: an introduction, Gender, Place \& Culture, 11 (2): 205208.(http://www.tandfonline.com/doi/abs /10).

Ashok, A., Snehalatha, N., Premkumar and Carter, J. 2005. Participatory monitoring and evaluation: field experiences, NGO ProgrammeKarnataka-Tamil Nadu, Series I, 2005, Inter Cooperation Delegation, Hyderabad, 33-38.

Farid, K.S., Mozumdar, L., Kabir, M.S. and Goswami, U.K. 2009. Nature and extent of rural women's participation in Agricultural and non-agricultural activities. Agric. Sci. Digest, 29 (4): 254-259.

Hellin, J., Bellon, M. and Badstue, L. 2006. Bridging the gaps between researchers' and farmers' realities, LEISA India, September 2006, p. 6.

Jaiswal, N.K. and Das, P.K. 1981. Transfer of technology in rice farming, Rural Development Digest, 4 (4): 320-353.

Lipishree, D. 2015. Work Participation of Women in Agriculture in Odisha. IOSR Journal of Humanities and Social Science (IOSR-JHSS. 20 (7-Ver. III): 
66-78.

Mayoux, L. 1999. Questioning virtuous spirals: microfinance and women's empowerment in Africa. Journal of International Development: 957-984.

Nagaraja, N. 2003. Farmers field schools implementation guidelines. Gayathri book company, Bangalore.

NGO Programme Karnataka-Tamil Nadu (2005). Participatory monitoring and evaluation: field experiences, NGO Programme- Karnataka-Tamil Nadu, Series I, 2005, Inter Cooperation Delegation, Hyderabad.
Reddy, L. N. 2006. Participatory technology and development, LEISA India, September 2006, p. 27.

Sahoo, L.K. 2011. Report on socio-economic profile of tribal populations in Mayurbhanj and Keonjhar Districts (http://orissa.gov.in/emagazine/Orissare view/2011/may/engpdf/63-68.pdf).

WHO. 2007. "The WHO Child Growth Standards", World Health Organization. (Available from: http://www.who.int/ childgrowth/standards/en/, accessed on December 24, 2015).

\section{How to cite this article:}

Charles Jeeva, J., Gayatri Moharana, Kushagra Joshi, B.C. Behera and Subrat Kr. Das. 2019. Gender Mainstreaming: A Participatory Impact Assessment of Livelihood Interventions among the Tribal Farm Families in Odisha, India. Int.J.Curr.Microbiol.App.Sci. 8(07): 2457-2464. doi: https://doi.org/10.20546/ijcmas.2019.807.302 